\title{
Pengaruh Brand Awareness terhadap Consumer Decision Making The Influence of Brand Awareness to Consumer Decision Making
}

\author{
Rianty Ameliawaty ${ }^{1 *}$ dan Ii Halilah ${ }^{2}$ \\ ${ }^{1}$ Jurusan Administrasi Niaga Politeknik Negeri Bandung Indonesia \\ ${ }^{2}$ Jurusan Administrasi Niaga Politeknik Negeri Bandung Indonesia
}

\begin{abstract}
:
This study to find out how brand awareness in CFC Bandung, how consumer purchasing decisions in CFC Bandung, and how the influence of brand awareness of purchasing decisions in CFC Bandung. This research is done by using quantitative method with descriptive data analysis. The number of samples in this study was 117 consumers who ever made a purchase in CFC Bandung. Reliability test, $R^{2}$, hypothesis test, simple regression was used in this research. The results show that brand awareness has an influence with $R^{2} 49 \%$ by having a significant positive relationship is very strong. The regression equation that can be obtained in this research is $Y=2.494+0.370 X$. Brand awareness has a simple linear regression value of 0.370. This study shows that brand awareness has an influence on consumer purchasing decision in CFC Bandung.
\end{abstract}

Keywords: brand awareness, consumer behavior, consumer decision making

\begin{abstract}
Abstrak:
Penelitian ini untuk mengetahui bagaimana brand awareness di CFC Bandung, bagaimana keputusan pembelian konsumen di CFC Bandung, dan bagaimana pengaruh brand awareness terhadap keputusan pembelian di CFC Bandung. Penelitian ini dilakukan dengan menggunakan metode kuantitatif dengan analisis data deskriptif. Jumlah sampel dalam penelitian ini adalah 117 konsumen yang pernah melakukan pembelian di CFC Bandung. Uji reliabilitas, $\mathrm{R}^{2}$, uji hipotesis, dan regresi sederhana digunakan pada penelitian ini. Hasil penelitian menunjukkan bahwa kesadaran merek memiliki pengaruh dengan $\mathrm{R}^{2} 49 \%$ dan memiliki hubungan positif yang sangat kuat secara signifikan. Persamaan regresi yang dapat diperoleh dalam penelitian ini adalah $\mathrm{Y}=2,494+0,370 \mathrm{X}$. Kesadaran merek memiliki nilai regresi linier sederhana yaitu 0,370. Penelitian ini menunjukkan bahwa brand awareness berpengaruh terhadap keputusan pembelian konsumen di CFC Bandung.
\end{abstract}

Kata kunci: kesadaran merek, perilaku konsumen, pengambilan keputusan konsumen

\section{PENDAHULUAN}

Di era persaingan dunia bisnis yang ketat ini, pelaku bisnis dituntut untuk mampu bersaing dengan perusahaan

\footnotetext{
* Email Korespondensi:

Rianty Ameliawaty

Riantyabd4@yahoo.com
}

lainnya, dimana persaingan telah menjadi menu utama sehari-hari yang harus dihadapi oleh para pelaku bisnis, terutama bisnis dalam bidang fast food. Fast food merupakan makanan cepat saji yang banyak dibutuhkan oleh orang-orang, karena dengan adanya fast food kebutuhan 
konsumen akan makanan yang praktis dan cepat saji bisa terpenuhi. Oleh karena itu banyak pebisnis dalam bidang fast food berlomba-lomba untuk bersaing membangun strategi bisnis yang baik agar mampu menarik para konsumen, salah satunya melalui persaingan merek.

Merek mempunyai peran penting bagi kelangsungan hidup sebuah perusahaan. Persaingan untuk merebut konsumen melalui sebuah merek akan terus terjadi. Merek bukan hanya dianggap sebagai sebuah nama, logo atau simbol, lebih dari itu merek juga adalah nilai yang ditawarkan sebuah produk bagi konsumen yang memakainya. Bagi konsumen, merek mampu menambah persepsi dan keyakinan atas pembelian produk sehingga konsumen tidak segan membayar mahal untuk mendapatkan produk dengan merek tertentu. Konsumen bersedia membayar lebih tinggi produk tersebut karena terdapat merek yang merupakan jaminan konsistensi kualitas dan nilai tertentu yang diyakini terkandung didalamnya.

Dalam hal merek, konsumen harus memiliki kesadaran merek (brand awareness) atas suatu produk, karena sebelum konsumen melakukan keputusan pembelian, konsumen biasanya membandingkan beberapa alternatif yang terdapat di pasaran dan kelebihan dari masing-masing merek. Hal tersebut menunjukan bahwa pentingnya brand awareness suatu produk dalam persaingan dan dalam mempengaruhi keputusan pembelian yang mampu meningkatkan penjualan.

California Fried Chicken (CFC) adalah restoran waralaba makanan yang menghasilkan ayam. Perusahaan ini didirikan pada tahun 1983 di Jakarta. Hingga saat ini, CFC memiliki lebih dari 180 gerai di seluruh Indonesia. Keberadaan berbagai macam fast food menuntut CFC harus terus bersaing untuk mendapatkan konsumen, terutama bersaing dalam merek.
CFC dalam pandangan konsumen masih belum memiliki brand awareness yang tinggi, ditunjukan dengan hasil Top Brand Award 2016, dimana CFC tidak termasuk ke dalam tiga besar Top Brand Award 2016 sebagai fast food bermerek pilihan konsumen.

CFC memiliki TBI $2.0 \%$ dan fast food lainnya yaitu KFC memiliki TBI) sebesar $63.9 \%$, MC Donald's dengan TBI sebesar $18.6 \%$, A\&W dengan TBI sebesar $2.6 \%$ dan terakhir Hoka-hoka Bento memiliki TBI sebesar $2.5 \%$, dengan presentase TBI CFC yang menunjukan dibawah $10 \%$, menunjukan bahwa CFC masih belum menjadi pilihan masyarakat karena standar untuk menjadi posisi tiga terbaik harus memiliki TBI dengan minimum $10 \%$. Hasil survey tersebut diperoleh berdasarkan tiga parameter yakni (1) top of mind awareness, yaitu berdasarkan brand yang pertama kali disebut oleh responden ketika mereka mendengar kategori produk (2) last used, yaitu berdasarkan brand yang digunakan terakhir kali oleh responden dalam satu periode pembelian (3) future intention, yaitu berdasarkan brand yang responden niatkan akan digunakan di masa yang akan datang.

Tabel 1. Top Brand 2016 Kategori Fast Food Bermerek

\begin{tabular}{|l|l|l|}
\hline MEREK & TBI & TOP \\
\hline KFC & $63,9 \%$ & TOP \\
\hline MC'Donalds & $18,6 \%$ & TOP \\
\hline A \& W & $2,6 \%$ & \\
\hline $\begin{array}{l}\text { Hoka-hoka } \\
\text { Bento }\end{array}$ & $2,5 \%$ & \\
\hline CFC & $2,0 \%$ & \\
\hline
\end{tabular}

Sumber: Top Brand Award

Salah satu kategori dalam TBI yang menunjukkan bahwa brand awareness CFC masih dianggap berada di tingkatan 
rendah yaitu top of mind awareness. Hal tersebut didukung oleh hasil wawancara mengenai brand awareness dalam kategori fast food pada 30 responden oleh peneliti, yang menunjukkan bahwa tiga puluh responden tidak menyebutkan CFC sebagai merek pertama yang disebutkan oleh responden.

Hal-hal yang dipengaruhi oleh brand awareness salah satunya yaitu keputusan pembelian konsumen. Merek yang kuat lebih memudahkan konsumen untuk melakukan keputusan pembelian saat akan melakukan transaksi pembelian karena pembeli cenderung akan melakukan pembelian terhadap produk yang sudah dikenalinya. Selain itu kesadaran merek juga merupakan langkah pertama dalam membangun brand equity.

\section{KAJIAN LITERATUR Pengertian Merek}

Menurut Rangkuti (2008) merek merupakan sebuah nama atau simbol (seperti logo, merek dagang, desain kemasan, dan sebagainya) yang dibuat untuk membedakan satu produk dengan produk lainnya. Selain itu, merek yang telah dipatenkan dapat membuat produk tersebut menjadi lebih terlindungi dari upaya pemalsuan dan pembajakan. Sedangkan menurut Kotler (dalam Wijayanto, 2010) merek adalah nama, istilah, tanda, simbol, rancangan, atau kombinasi dari hal-hal tersebut, yang dimaksudkan untuk mengidentifikasi barang atau jasa dari seorang atau sekelompok penjual dan untuk membedakannya dari produk pesaing. Berdasarkan kedua teori tersebut dapat disimpulkan bahwa merek merupakan nama atau simbol yang digunakan perusahaan untuk suatu produk yang akan dipasarkan agar membedakannya dari produk pesaing.

\section{Pengertian Brand Equity}

Jurnal Riset Bisnis \& Investasi

Vol. 3, No. 2, Agustus 2017

ISSN 2460-8211
Menurut Kotler dan Keller (2009), ekuitas merek adalah nilai tambah yang diberikan pada produk dan jasa. Ekuitas merek dapat tercermin dalam cara konsumen berpikir, merasa dan bertindak dalam hubungannya dengan merek, dan juga harga, pangsa pasar, dan profitabilitas yang diberikan merek bagi perusahaan. Menurut Aaker (dalam, Tjiptono, 2014:117), ekuitas merek adalah "serangkaian aset dan kewajiban (liabilities) merek yang terkait dengan sebuah merek, nama dan simbolnya, yang menambah atau mengurangi nilai yang diberikan sebuah produk atau jasa kepada perusahaan dan/atau pelanggan perusahaan tersebut." Berdasarkan kedua teori tersebut dapat disimpulkan bahwa ekuitas merek merupakan nilai yang terkandung dalam suatu merek yang ada dalam pikiran konsumen, dan dari apa yang konsumen rasakan dari merek tersebut. (Aaker dalam Sumarwan 2009) menjelaskan bahwa ekuitas merek memiliki lima komponen, yaitu kesadaran merek, asosiasi merek, persepsi kualitas, loyalitas merek dan nilai-nilai merek lainnya.

\section{Pengertian Kesadaran Merek}

Kesadaran merek atau brand awareness adalah kesanggupan seseorang calon pembeli untuk mengenali atau mengingat kembali bahwa merek merupakan bagian dari kategori produk tertentu (Wijayanto, 2010). Sedangkan menurut Wahyudi (2012), brand awareness adalah suatu keadaan dimana merek suatu produk dikenal oleh pelanggan potensial dan diasosiasikan dengan tepat terhadap jenis kategori produk tertentu. Selanjutnya, menurut Durianto dkk (2004) kesadaran (awareness) menggambarkan keberadaan merek didalam pikiran konsumen, yang dapat menjadi penentu dalam beberapa kategori dan biasanya mempunyai peranan kunci dalam brand equity. 
Brand awareness sering dijadikan sasaran utama periklanan dalam bulanbulan atau tahun-tahun awal dari suatu pengenalan produk baru. Konsumen akan cenderung membeli merek yang sudah dikenal karena merasa aman dengan sesuatu yang sudah dikenal. Dengan kata lain, sebuah merek yang dikenal mempunyai kemungkinan bisa diandalkan, kemantapan dalam bisnis, dan kualitas yang bisa dipertanggung jawabkan sehingga konsumen cenderung membeli merek yang sudah terkenal tersebut. Berdasarkan teoriteori tersebut dapat disimpulkan bahwa brand awareness merupakan kesadaran seorang pembeli untuk mengenal suatu merek dalam kategori produk tertentu.

\section{Indikator Brand Awareness}

Aaker (1996) mengemukakkan bahwa ada beberapa tingkatan awareness yang digunakan sebagai alat ukur untuk mengetahui brand awareness pada suatu produk yaitu sebagai berikut:

1. Brand recognition

Brand recognition merupakan seberapa jauh konsumen dapat mengenali merek tersebut termasuk dalam satu kategori tertentu.

2. Brand recall

Brand recall adalah pengingatan kembali brand tanpa bantuan (unaided recal) dan juga seberapa jauh konsumen dapat mengingat ketika ditanya merek apa saja yang mereka ingat.

3. Top of mind

Top of mind (puncak pikiran) adalah brand yang disebutkan pertama kali oleh konsumen atau yang pertama kali muncul dalam benak konsumen, atau brand tersebut merupakan brand utama dari berbagai brand yang ada dalam benak konsumen.

4. Brand dominance

Samu dan Wymer (2008) menyatakan bahwa "dominance is the degree to which a particular message differentially emphasizes the brand and/or the cause".

5. Brand knowledge (Pengetahuan Merek) Brand knowledge yaitu menilai bagaimana pelanggan memandang dan mengevaluasi sebuah merek (Rudolf Esch, et al., 2006). Pengetahuan merek atau brand knowledge didefinisikan sebagai adanya informasi tentang merek dalam ingatan konsumen, beserta dengan asosiasi - asosiasi yang berkaitan dengan merek tersebut (Keller, 1993).

6. Brand opinion

Brand opinion adalah pendapat konsumen baik positif maupun negatif mengenai produk, jasa, dan brand (Goyette, et al., 2010).

\section{Indikator Consumer Decision Making}

Menurut Kotler dan Keller (2009), konsumen mungkin juga membentuk maksud untuk membeli merek yang paling disukai. Sedangkan dimensi pengambilan keputusan pembelian konsumen menurut Sudaryono (2014):

1. Pilihan Produk (Product Choice)

Konsumen menentukan produk mana yang akan dibeli, konsumen akan membeli produk yang memiliki nilai baginya. Perusahaan harus mengetahui produk seperti apa yang diinginkan konsumen.

2. Pilihan Merek (Brand Choice)

Konsumen harus menentukan merek mana yang akan dibeli, setiap merek memiliki perbedaan-perbedaan tersendiri. Dalam hal ini perusahaan harus mengetahui bagaimana konsumen memilih sebuah merek.

3. Pilihan Penyalur (Dealer Choice)

Konsumen harus mengambil keputusan tentang penyalur mana yang akan di kunjungi. Setiap konsumen berbedabeda dalam hal menentukan penyalur, dapat dikarenakan faktor lokasi yang dekat, harga yang murah, persediaan 
barang yang lengkap, kenyamanan berbelanja, dan keleluasaan tempat. Dalam hal ini, produsen, pedagang besar dan pengecer harus mengetahui bagaimana konsumen memilih penjual tertentu.

4. Jumlah Pembelian (Purchase Amount) Jumlah pembelian yaitu jumlah produk yang akan dibeli oleh konsumen. Konsumen dapat mengambil keputusan tentang seberapa jumlah produk yang akan dibelinya pada suatu saat. Pembelian yang dilakukan mungkin lebih dari satu unit. Dalam hal ini perusahaan-perusahaan harus mempersiapkan banyak produk sesuai dengan keinginan yang berbeda-beda dari para pembeli.

5. Waktu Pembelian (Purchase Timing)

Konsumen dapat mengambil keputusan tentang kapan ia harus melakukan pembelian. Masalah ini akan menyangkut tersedianya uang untuk membeli produk. Oleh karena itu perusahaan harus mengetahui faktorfaktor yang mempengaruhi keputusan konsumen dalam penentuan waktu pembelian. Dengan demikian perusahaan dapat mengatur waktu produksi dan kegiatan pemasarannya.

6. Metode Pembayaran (Payment Methods)

Keputusan tentang cara pembayaran. Konsumen harus mengambil keputusan tentang metode atau cara pembayaran produk yang dibeli. Keputusan konsumen dalam menentukan jenis pembayaran, diantaranya adalah kartu kredit, voucer, dan kartu debit dan lainlain. Dengan demikian konsumen dapat melakukan pemilihan alternatif berdasarkan pertimbangan diatas untuk memperoleh keputusan yang terbaik bagi konsumen. Keputusan tersebut akan mempengaruhi keputusan tentang penjual dan jumlah pembeliannya.

\section{Hubungan Brand Awareness dengan Consumer Decision Making}

Merek menjadi pertimbangan yang penting dalam pembelian sebuah produk. Suatu merek yang kesadarannya tinggi akan membantu asosiasi-asosiasi melekat pada merek tersebut karena daya jelajah merek tersebut menjadi sangat tinggi di benak konsumen. Sebaliknya, jika kesadaran akan merek tersebut rendah, suatu asosiasi yang diciptakan oleh pemasar akan sulit melekat pada merek tersebut. Jika kesadaran akan suatu merek tinggi, konsumen akan sangat akrab dengan merek tersebut, dan lamakelamaan akan timbul rasa suka yang tinggi terhadap merek yang dipasarkan.

Sebuah merek dengan kesadaran konsumen yang tinggi biasanya disebabkan oleh beberapa faktor, yaitu yang diiklankan secara luas, eksistensi yang sudah teruji dengan waktu, jangkauan distribusi yang luas dan merek tersebut dikelola dengan baik. Dapat dinyatakan bahwa ternyata kesadaran merek bisa menjadi faktor independen yang penting dalam perubahan sikap. Implikasinya, kesadaran dipengaruhi oleh periklanan yang bersifat mengingatkan kembali dimana akan mempengaruhi keputusan-keputusan pembelian. Menurut Swastha dan Handoko (2011) keputusan pembelian merupakan proses dalam pembelian yang nyata apakah membeli atau tidak. Menurut Kotler \& Amstrong (2012) proses keputusan pembelian terdiri dari lima tahap yang dilakukan oleh seorang konsumen sebelum sampai pada keputusan pembelian dan selanjutnya setelah pembelian.

Merek yang kuat lebih memudahkan konsumen untuk melakukan keputusan pembelian ulang saat akan melakukan transaksi pembelian. Hal ini sejalan dengan pendapat yang dikemukakan oleh Durianto dkk (2004) bahwa pada umumnya konsumen cenderung membeli produk dengan merek yang sudah dikenalnya atas dasar 
pertimbangan kenyamanan, keamanan dan lain-lain. Menurut Chi dalam (Akhtar, 2016) brand awareness adalah hal penting yang dapat mempengaruhi keputusan pembelian karena ketika pelanggan ingin membeli produk, citra merek atau brand nama langsung datang ke pikiran mereka. Ambolau dkk (2015) dan Yaseen et al (2011) menyatakan bahwa brand awareness berpengaruh secara signifikan terhadap keputusan pembelian. Pernyataan yang sama juga dijelaskan oleh Aryan (2012) dan Timpal dkk (2014) bahwa brand awareness berpengaruh secara signifikan terhadap keputusan pembelian konsumen. Menurut Hoyer \& Brown dalam (Dhurup, 2014) kesadaran merek mempengaruhi pengambilan keputusan konsumen dalam berbagai cara. Misalnya, konsumen dapat menggunakan brand awareness sebagai jangkar dalam keputusan pembelian mereka. Dengan demikian, hipotesis dalam penelitian ini adalah:

$\mathrm{H}_{\mathrm{o}}$ : Tidak terdapat pengaruh positif dan signifikan antara brand awareness terhadap keputusan pembelian konsumen di California Fried Chicken.

Ha : Ada pengaruh positif dan signifikan antara brand awareness terhadap keputusan pembelian konsumen di California Fried Chicken.

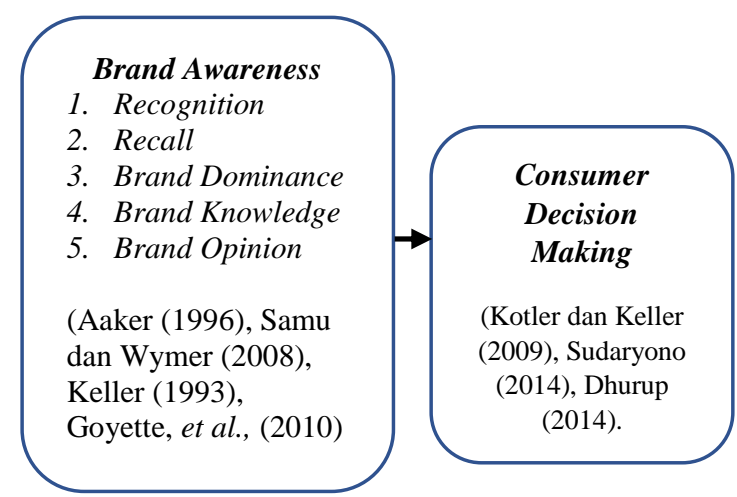

Gambar 1. Model Penelitian

\section{METODE PENELITIAN}

Data dalam penelitian ini dikumpulkan melalui data primer berupa data hasil observasi dan kuesioner yang diisi oleh responden dan data sekunder yang diperoleh dari dari buku, jurnal ilmiah, dan hasil penelitian sebelumnya yang berkaitan dengan brand awarenees dan keputusan pembelian konsumen.

Populasi dalam penelitian ini merupakan populasi infinite karena penelitian ini dilakukan pada pengunjung yang jumlahnya tidak diketahui. Dalam penelitian ini, populasi yang ditujukan adalah seluruh konsumen CFC di Kota Bandung. Sedangkan jumlah sampel dalam penelitian ini yaitu 117 orang konsumen yang ditemui dan dianggap cocok untuk menjadi responden pada saat proses pengamatan berlangsung. Teknik sampling yang digunakan dalam penelitian ini adalah non probability sampling dengan cara pengambilan sampel menggunakan quota sampling. Dimana pengambilan data ini selesai sampai jumlah (kuota) dalam penyeberan kuesioner telah terpenuhi.

\section{HASIL DAN PEMBAHASAN Analisis Deskriptif}

Hasil analisis deskriptif brand awareness menunjukkan bahwa variabel brand awareness memiliki nilai mean sebesar 3,10 dengan standar deviasi 0,568. Nilai 3,10 dikategorikan cukup baik/cukup tinggi. Sementara itu, nilai standar deviasi menunjukkan angka 0,568 yang berada dibawah $20 \%$ dari nilai mean yaitu $18,32 \%$. Standar deviasi yang kurang $20 \%$ dari nilai mean menunjukkan adanya variasi yang kecil dan semua responden setuju dengan pernyataan variabel brand awareness. Dengan kata lain, responden menunjukkan persepsi yang hampir sama mengenai brand awareness yang cukup baik.

Pada Tabel 2 dapat diketahui bahwa dari lima dimensi yang menentukan brand awareness, dimensi Recall merupakan 
dimensi dengan nilai mean tertinggi yaitu 4.31. Sedangkan dimensi dengan nilai mean terendah adalah dimensi brand dominance yaitu sebesar 1.74.

Dari Tabel 3 dapat diketahui bahwa diantara enam pernyataan pada variabel keputusan pembelian konsumen, pernyataan dengan mean paling tinggi yaitu melakukan keputusan pembelian atas dasar pilihan produk sebesar 2.95 dan pernyataan yang memiliki mean terkecil yaitu keputusan pembelian atas dasar metode pembayaran sebesar 2.77. Pada variabel keputusan pembelian memiliki mean sebesar 2.62.

\section{Uji Korelasi}

Metode analisis korelasi sederhana ini digunakan untuk mengetahui adanya hubungan antar variabel. Pada Tabel 4 dapat dilihat korelasi antara variabel brand awareness dan keputusan pembelian konsumen sebesar 0,700 yang berarti terdapat hubungan positif yang sangat kuat antara brand awareness dengan keputusan pembelian konsumen. Hal ini berarti bahwa semakin baik brand awareness dirasakan oleh pelanggan maka tingkat keputusan pembelian konsumen akan semakin baik.

\section{Uji Regresi Linear Sederhana}

Analisis regresi digunakan untuk mengetahui seberapa besar pengaruh brand awareness terhadap keputusan pembelian konsumen. Dari Tabel 5 dapat diketahui konstanta (a) bernilai 2.494 dengan koefisien regresi (b) sebesar 0.370. Oleh karena itu, persamaan regresi yang dapat diperoleh dalam penelitian ini adalah $\mathrm{Y}=2.494+0,370 \mathrm{X}$. Konstanta sebesar 2.494 dapat diartikan jika brand awareness sama dengan nol $(\mathrm{X}=0)$, maka pengambilan keputusan pembelian konsumen sebesar 2.494 .

Brand awareness memiliki nilai koefisien regresi linear sederhana sebesar 0,370 . Hal ini mengandung arti bahwa apabila brand awareness mengalami kenaikan satu satuan maka pengambilan keputusanpembelian konsumen akan mengalami kenaikan sebesar 0,370 satuan.

Tabel 2. Hasil Analisis Deskriptif Brand Awareness

\begin{tabular}{|c|c|c|c|c|c|}
\hline & $\mathbf{N}$ & Min & Max & Mean & Std. Deviation \\
\hline Recognition & 117 & 2 & 5 & 3.52 & .733 \\
\hline Recall & 117 & 1 & 5 & 4.31 & .728 \\
\hline Top of mind & 117 & 1 & 5 & 2.05 & .878 \\
\hline Brand dominance & 117 & 1 & 5 & 1.74 & .747 \\
\hline Brand Knowledge & 117 & 1 & 5 & 2.86 & .935 \\
\hline Brand Opinion & 117 & 1 & 5 & 2.70 & .910 \\
\hline Brand Awareness & $\mathbf{1 1 7}$ & $\mathbf{1}$ & $\mathbf{5}$ & $\mathbf{3 . 1 0}$ & $\mathbf{. 5 6 8}$ \\
\hline
\end{tabular}

Sumber: Hasil Olah Data SPSS (2017)

Tabel 3. Hasil Analisis Deskriptif Pengambilan Keputusan Konsumen

\begin{tabular}{|c|c|c|c|c|c|}
\hline & $\mathbf{N}$ & Min & Max & Mean & Std. Deviation \\
\hline Pilihan produk & 117 & 1 & 5 & 2.95 & .972 \\
\hline Pilihan merek & 117 & 1 & 5 & 2.77 & .995 \\
\hline Pilihan penyalur & 117 & 1 & 5 & 2.83 & .950 \\
\hline Waktu pembelian & 117 & 1 & 5 & 2.39 & 1.008 \\
\hline Jumlah pembelian & 117 & 1 & 5 & 2.74 & .882 \\
\hline Metode pembayaran & 117 & 1 & 5 & 2.62 & .817 \\
\hline Keputusan Pembelian & $\mathbf{1 1 7}$ & $\mathbf{1}$ & $\mathbf{5}$ & $\mathbf{2 . 7 2}$ & $\mathbf{. 6 6 7}$ \\
\hline
\end{tabular}

Sumber: Hasil Olah Data SPSS (2017) 
Tabel 4. Hasil Uji Korelasi Pelanggan

\begin{tabular}{|ll|r|r|}
\hline & & Brand Awareness & $\begin{array}{c}\text { Consumer Decision } \\
\text { Maling }\end{array}$ \\
\hline Brand Awareness & Pearson Correlation & 1 & $.700^{-7}$ \\
& Sig. (2-tailed) & 117 & .000 \\
& $\mathrm{~N}$ & $.700^{*-}$ & 117 \\
\hline Keputusan Pembelian & Pearson Correlation & .000 & 1 \\
& Sig. (2-tailed) & 117 & 117 \\
& $\mathrm{~N}$ & & \\
& & & 117 \\
\hline
\end{tabular}

Correlation is significant at the 0.01 level (2-tailed)

Sumber: Hasil Olah Data SPSS (2017)

Tabel 5. Hasil Uji Regresi Linear Sederhana

\begin{tabular}{|c|c|c|c|c|c|}
\hline \multirow{2}{*}{ Model } & \multicolumn{2}{|c|}{ Unstandardized Coefficients } & \multirow{2}{*}{$\begin{array}{c}\text { Standardized Coefficients } \\
\text { Beta }\end{array}$} & \multirow{2}{*}{$\mathbf{t}$} & \multirow{2}{*}{ Sig. } \\
\hline & B & Std. Error & & & \\
\hline 1 (Constant) & 2.494 & 1.340 & & 1.861 & .065 \\
\hline Brand Awareness & 0.370 & .035 & .700 & 10.514 & .000 \\
\hline
\end{tabular}

Sumber : Hasil Olah Data SPSS (2017)

\section{Koefisien Determinasi}

Pada Tabel 6 menunjukkan hasil $\mathrm{R}$ square (koefisien determinasi) sebesar $0.490(49 \%)$ yang merupakan hasil kuadrat dari 0.700. Dalam hal ini berarti $49 \%$ keputusan pembelian konsumen bisa dijelaskan oleh brand awareness, sedangkan sisanya $(100 \%-49 \%=51 \%)$ disebabkan oleh faktor-faktor lain seperti store atmosphere, pelayanan, kualitas produk, dan lain lain.

Tabel 6. Hasil Koefisien Determinasi

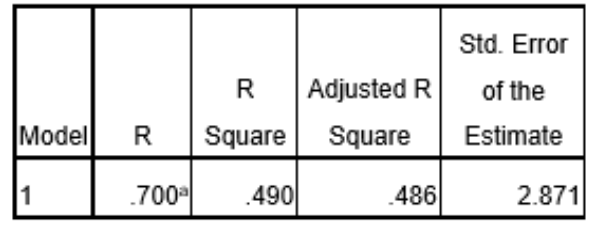

Sumber: Hasil Olah Data SPSS (2017)

\section{Pengaruh Brand Awareness Terhadap Consumer Decision Making}

Berdasarkan data demografi responden yang merupakan konsumen $\mathrm{CFC}$ di Kota Bandung, dapat diketahui bahwa $60.68 \%$ dari konsumen CFC di Kota
Bandung adalah perempuan. Hal itu terlihat saat melakukan penelitian di CFC di Kiaracondong mayoritas yang mengunjungi $\mathrm{CFC}$ adalah perempuan baik anak balita, remaja, maupun dewasa. Kemudian untuk usia konsumen CFC di Kota Bandung, didapatkan hasil bahwa $51.2 \%$ adalah usia 17-21 yang merupakan usia dengan persentase yang paling tinggi. Kemudian berkesinambungan dengan mayoritas usia konsumen CFC yaitu 70.9\% mayoritas pekerjaan dari konsumen yaitu mahasiwa atau pelajar, untuk rata-rata tertinggi dari penghasilan atau pendapatan konsumen di kota Bandung $41.8 \%$ memiliki penghasilan lebih dari Rp.1500.000, hal ini berarti bahwa produk CFC diminati oleh pasar menengah ke atas. Hasil penelitian menunjukan bahwa terdapat hubungan yang sangat besar antara brand awareness dengan keputusan pembelian konsumen. Hal tersebut dapat dilihat pada hasil analisis korelasi antara variabel brand awareness dengan keputusan pembelian konsumen sebesar 0.700 termasuk kedalam interval +0.70 
yang artinya terdapat hubungan positif yang sangat kuat (Bungin, 2010). Selain itu berdasarkan analisis regresi yang dilakukan pada penelitian ini, dapat diketahui bahwa brand awareness memiliki pengaruh yang positif terhadap keputusan pembelian. Hal tersebut dapat dilihat dari persamaan analisis regresi linear sederhana yang dihasilkan, yaitu $\mathrm{Y}=2.494+0.370$. Dari persamaan regresi linear sederhana tersebut, diketahui nilai konstanta sebesar 2.494. sedangkan koefisien regresi menunjukan angka 0.370 yang menjelaskan bahwa setiap penambahan satu angka brand awareness dengan koefisien regresi bernilai positif maka kesadaran merek konsumen terhadap CFC akan meningkat.

Berdasarkan koefisien determinasi, brand awareness memberikan kontribusi pengaruh sebesar 49\% terhadap keputusan pembelian. Sedangkan $51 \%$ lainnya dipengaruhi oleh kontribusi faktor lain yang tidak terdapat dalam penelitian ini. Sesuai dengan penelitian Aryan (2012) bahwa brand awareness berpengaruh secara signifikan terhadap keputusan pembelian, dalam penelitian ini bedanya yaitu persentase yang paling tinggi dari penelitian ini berada pada dimensi top of mind yang menyatakan bahwa minuman air Aqua dikenal luas oleh masyarakat, dengan persentase sebesar $89.2 \%$, dan penelitian ini hanya menggunakan tiga dimensi yaitu top of mind, brand recall, dan brand recognition. Kemudian penelitian dari Ambolau (2013) juga menyatakan bahwa pengaruh brand awareness dan brand image terhadap keputusan pembelian nilai $R^{2}$ nya sebesar $50.4 \%$ dengan tingkat signifikan di bawah 0.05 .

Dari tabel uji statistiK F, didapat nilai $\mathrm{F}$ hitung sebesar 110.536 dan didapat nilai $\mathrm{F}$ tabel sebesar 3.92 berdasarkan data tersebut, diketahui bahwa nila $\mathrm{F}$ hitung lebih besar dari $\mathrm{F}$ tabel, selain itu diketahui pula nilai signifikansi sebesar 0.000 (lebih kecil dari 0.05). dapat disimpulkan bahwa
$\mathrm{H}_{\mathrm{O}}$ ditolak dan $\mathrm{H}_{\mathrm{a}}$ diterima, yang berarti terdapat pengaruh yang signifikan dari brand awareness terhadap keputusan pembelian konsumen. Menurut Hoyer \& Brown dalam (Dhurup, 2014) kesadaran merek mempengaruhi pengambilan keputusan konsumen dalam berbagai cara. Misalnya, konsumen dapat menggunakan brand awareness sebagai jangkar nominal dalam keputusan pembelian mereka. Dengan demikian, dapat disimpulkan bahwa brand awareness yang tinggi dan merek yang sudah terkenal akan memberikan pengaruh yang besar terhadap proses keputusan pembelian yang dilakukan oleh konsumen.

Berdasarkan uji $\mathrm{t}$, diperoleh nilai $\mathrm{t}$ hitung sebesar 10.514 dan diperoleh nilai $\mathrm{t}$ tabel sebesar 1.980 Berdasarkan data tersebut, diperoleh nilai t hitung yang lebih besar dari t tabel 1.980 Dapat disimpulkan bahwa $\mathrm{H}_{\mathrm{a}}$ diterima dan $\mathrm{H}_{\mathrm{O}}$ ditolak, hal ini berarti ada pengaruh positif dan signifikan antara brand awareness dengan keputusan pembelian konsumen di CFC Kota Bandung. Selain itu, karena probabilitas jauh lebih kecil dari 0.05 yaitu sebesar 0.000 maka model regresi dapat digunakan untuk memprediksi keputusan pembelian konsumen. Dengan kata lain, brand awareness berpengaruh terhadap keputusan pembelian konsumen.

\section{KESIMPULAN DAN SARAN Kesimpulan}

Berdasarkan hasil peneltian mengenai pengaruh brand awareness di CFC Kota Bandung, dapat disimpulkan bahwa:

1. Brand awareness yang dimiliki CFC Kota Bandung berada dalam kategori cukup baik yaitu dengan nilai mean sebesar 3.10 artinya brand awareness yang dimiliki CFC belum bisa dikatakan benar-benar baik, karena 
masih banyak hal-hal yang harus ditingkatkan untuk mendapatkan kategori baik. Dimensi recall berada pada kategori sangat tinggi yang artinya konsumen sudah mengetahui bahwa CFC merupakan merek dalam kategori fast food. Tetapi dimensi brand dominance berada dalam kategori sangat rendah yang artinya konsumen tidak menjadikan CFC sebagai merek yang dominan menjadi pilihan mereka.

2. Mayoritas konsumen melakukan pembelian di CFC bukan karena mereknya yang sudah terkenal tapi karena produk nya sesuai kebutuhan mereka. Hal ini dapat dilihat pada hasil mengenai mengenai keputusan pembelian karena produk menghasilkan mean dengan jumlah 2.95, sedangkan untuk pengambilan keputusan pembelian karena merek menghasilkan mean dengan jumlah 2.77.

3. Pengaruh brand awareness terhadap pengambilan keputusan pembelian di CFC Kota Bandung pengaruhnya sangat besar. Konsumen tidak menjadikan CFC sebagai pilihan mereka dalam hal merek karena brand awareness yang dimiliki CFC masih belum dikatakan baik, dibuktikan dengan masyarakat yang lebih memilih merek yang lebih terkenal.

\section{Saran}

1. Karena brand awareness CFC masih belum bisa dikatakan baik, oleh karena itu CFC harus melakukan positioning yang tepat agar bisa meningkatkan brand awareness konsumen. Merek dapat dipositioning-kan dengan berbagai cara, misalnya dengan menempatkan posisinya secara spesifik di benak pelanggan. Membangun positioning adalah menempatkan semua aspek dari brand value (termasuk manfaat fungsional) secara konsisten sehingga selalu menjadi nomor satu di benak pelanggan. Salah satunya yaitu dengan melakukan diferensiasi produk yang berbeda dengan fast food lainnya, yang unik yang dapat menarik perhatian pelanggan. Misalnya dengan menciptakan produk ayam goreng yang dibalut dengan sambal rasa jagung bakar.

2. Kemudian untuk meningkatkn brand awareness CFC harus memiliki brand value yang tepat, karena semakin tepat merek di positioning-kan di benak pelanggan, merek tersebut akan semakin kompetitif. Oleh karena itu untuk mengelola hal tersebut perlu mengetahui brand value. Brand value dapat dilakukan dengan menciptakan produk-produk yang berkualitas yang mampu memberikan manfaat dan kepuasan bagi konsumen. Misalnya dengan menciptakan produk ayam goreng yang berkualitas baik, bersih, dan higienis yang dapat memberikan manfaat yang baik bagi konsumen. Kemudian menciptakan produk-produk yang disajikan dengan tempat atau penyajian yang unik yang memberikan kesan menarik dan keindahan bagi konsumen.

3. Selanjutnya, CFC harus memiliki konsep yang tepat untuk membangun dan mengkomunikasikan positioning dan brand value maka harus didukung dengan konsep yang tepat, yaitu dengan pengembangan konsep yang kreatif.

\section{DAFTAR PUSTAKA}

Aaker, D. (1996). Measuring Brand Equity Across Products and Markets. California Management Review, 38, 114-115.

Akhtar, N., Ain, Q. U., Siddiqi, U. I., Ashraf, A., \& Latif, M. (2016). Impact of Brand Equity on Consumer Purchase Decision in 
L'Oreal Skincare Products. International Review of Management and Business Research, 809.

Ambolau, M. A., Kusumawati, A., \& Mawardi, M. K. (2013). The Influence of Brand Awareness and Brand Image On Purchase Decision (Stydy On Aqua Consumers in Administrative Science Faculty Brawijaya University Class of 2013. Jurnal Administrasi Bisnis.

Ariyan, H. (n.d.). Pengaruh Brand Awareness dan Kepercayaan Konsumen atas Merek Terhadap Keputusan Pembelian Ulang Minuman Aqua di Kota Padang.

Bungin, B. (2010). Penelitian Kualitatif. Jakarta: Kencana Prenada Media Group.

Dhurup, M., Mafini, C., \& Dumasi, T. (2014). The impact of packaging, price and brand awareness on brand loyalty: evidence from the paint retailing industry. 4.

Durianto, A., \& Budiman, L. J. (2004). Brnd Equity Ten: Strategi
Memimpin Pasar. Jakarta: PT Gramedia Pustaka Utama.

Goyette, I., Ricard, L., Bergeron, J., \& Marticotte, F. (2010). e-WOM Scale: Word of Mouth Measurement Scale for e-Services Context. Canadian Journal of Administrative Sciences.

Keller, K. L. (1993). Conceptualizing, Measuring, and Managing Customer-Based Brand Equity. Journal of Marketing.

Kotler, P. \& Keller, K. L. (2009). Manajemen Pemasaran : Edisi Ketiga Belas. Jilid 1. Penerjemah: Bob Sabran. Jakarta: Erlangga.

Rangkuti, F. (2008). The Power of brands: Teknik mengelola brand equity dan strategi pengembangan merek analisis kasus dengan SPSS. Jakarta: PT Gramedia Pustaka Utama

Rudolf, E. F., Langner, T., Schmitt, B. H., \& Geus, P. (2006). Are brands forever? How Brand Knowledge and Relationship Affects Current and Future Purchases. Journal of Product \& Brand Management 